партнерства, поскольку данные лица наделены, согласно ч. 1 ст. 2 Закона равными правомочиями участия в управлении деятельностью партнерства наравне с его участниками.

Также, исходя из положений п. 5 ч. 7 от. 6 Закона, при присоединении к управлению партнерством, в том числе и иных лиц, которые не обязаны в участвовать в формировании складочного капитала партнерства, их вкладом может стать личное участие в хозяйственной деятельности партнерства. В этой связи, само партнерство в своей специфической организационно-правовой форме будет представлять собой просто объединение лиц, что тоже вызывает определенные сомнения.

Подводя итог, обозначенному исследованию вопросов структуры органов управления хозяйственным партнерством, необходимо дополнение Закона нормами, определяющими обязательность наличия в нем высшего органа управления (такого как общее собрание партнеров), в силу прямого указания Законом на необходимость волеизъявления всех участников партнерства и принятие единогласных решений по особо важным вопросам. Кроме того, следует сформулировать общие требования к порядку работы такого высшего органа управления, а также определить, возможность и четкие правила участия в нем иных лиц.

Представляется, что появление общего собрания партнеров, логически оформит общую систему органов управления партнерством, состоящую из формируемого в обязательном порядке единоличного исполнительного органа, а также других исполнительных органов партнерства.

$$
* * *
$$

1. Федеральный закон «О хозяйственных партнерствах» от 03 декабря 2011 г. № 380-Ф3 // Собрание законодательства Российской Федерации. 2011. № 49 (ч.5). Ст. 7058.

2. Пояснительная записка Пояснительная записка к проекту Федерального закона «О внесении изменений в часть первую Гражданского кодекса Российской Федерации в связи с принятием Федерального закона «О хозяйственных партнерствах» // СПС «Консультант Плюс».

3. Серова О.А. Хозяйственное партнерство и хозяйственное товарищество: возможные пути интеграции организационно-правовых форм // Законы России: опыт, анализ, практика. 2012. № 2. С. 35-39.

4. Суханов, Е. А. Хозяйственное партнерство или инвестиционная коммандита? // Развитие основных идей Гражданского кодекса России в современном законодательстве и судебной практике: Сборник статей, посвященный 70-летию С.А. Хохлова. - М.: Статут, 2011. - С. 173-187.

5. Федоров, И. М. Управление в хозяйственном партнерстве / И. М. Федоров // Закон. - 2012. - № 7. C. $95-104$.

6. Семенова Ю.А. Особенности создания складочного капитала хозяйственного партнерства // Бизнес в законе. 2014. № 5. С. 168-171.

\title{
Фатихова Л.М. \\ Правовые особенности наследования земельных участков в Российской Федерации
}

Башкирский государственный университет (Россия, Уфа)

doi:10.18411/spc-20-10-2017-14

idsp: 000001:spc-20-10-2017-14

Научный руководитель Тужилова-Орданская Е.М.

Основным гарантом прав граждан на земельные участки, в том числе те, которые используются для ведения садоводства, огородничества и дачного хозяйства, является Конституция РФ. В ее ст. 2 провозглашено, что непоколебимой обязанностью государства является признание, соблюдение и защита свобод гражданина и его основных прав. Защита этих прав и свобод гражданина в Российской Федерации 
гарантировано ст. 45 Конституции РФ. Любой гражданин РФ имеет право защищать свою свободу и свои права любыми способами, которые не запрещены законом.

Помимо Земельного Кодекса РФ, понятия некоторых видов земельных участков раскрываются в Законе о садоводах.

Садовый земельный участок - земельный участок, предоставленный гражданину или приобретенный им для выращивания плодовых, ягодных, овощных, бахчевых или иных сельскохозяйственных культур и картофеля, а также для отдыха (с правом возведения жилого строения без права регистрации проживания в нем и хозяйственных строений и сооружений).

Огородный земельный участок - земельный участок, предоставленный гражданину или приобретенный им для выращивания ягодных, овощных, бахчевых или иных сельскохозяйственных культур и картофеля (с правом или без права возведения некапитального жилого строения и хозяйственных строений и сооружений в зависимости от разрешенного использования земельного участка, определенного при зонировании территории).

Дачный земельный участок - земельный участок, предоставленный гражданину или приобретенный им в целях отдыха (с правом возведения жилого строения без права регистрации проживания в нем или жилого дома с правом регистрации проживания в нем и хозяйственных строений и сооружений, а также с правом выращивания плодовых, ягодных, овощных, бахчевых или иных сельскохозяйственных культур и картофеля) .

Определение земельного участка содержится в Земельном кодексе РФ (далее ЗК РФ). В соответствии с п. 2 ст. 6 Кодекса земельный участок как объект земельных отношений - это часть поверхности земли (в том числе почвенный слой), границы которой описаны и удостоверены в установленном порядке. На основании п. 1 ст. 261 ГК РФ территориальные границы земельного участка определяются в порядке, установленном земельным законодательством, на основе документов, выдаваемых собственнику государственными органами по земельным ресурсам и землеустройству.

Земельный участок, исходя из ст. 134 ГК РФ, является сложной вещью, так как участок - комплекс разнородных вещей, образующий целое, которое рассчитано на его использование по общему назначению. Отталкиваясь от ст. 261 ГК РФ, законодательство определяет сложный объект по двум основным характеристикам:

1) примерное перечисление объектов (поверхностный (почвенный) слой, замкнутые водоемы, находящиеся на участке лес и растения);

2) все, что находится над и под поверхностью этого участка.

Статья 6 ЗК РФ указывает, что земельные участки бывают: неделимыми и делимыми. Делимый участок - это значит, что его возможно размежевать на определенные части, которые в свою очередь после этого межевания образуют самостоятельные земельные участки, которые в дальнейшем возможно использовать без перевода их в состав земель иной категории, за исключением случаев, установленных федеральными законами . В таких случаях в роли объектов земельных отношений вступают: земля (как природный объект и природный ресурс), земельные участки или его части.

Статья 1181 ГК РФ предполагает, что земельные участки, которые принадлежат наследодателю на праве собственности или на праве пожизненного наследуемого владения, наследуются на общих основаниях. Документы правоустанавливающие, которые свидетельствуют о правах наследодателей на земельные участки это свидетельство о праве собственности (о праве на пожизненное наследуемое владение), которое выдается учреждениями юстиции, осуществляющими регистрацию прав на недвижимое имущество и сделок с ним. 
Следует обратить внимание на то, что только свидетельства, которые выданы комитетами по земельным ресурсам и землеустройству до введения в действие Федерального закона от 21 июля 1997 г. № 122-Ф3 «О государственной регистрации прав на недвижимое имущество и сделок с ним» (т.е. до 31 января 1998 г.), также которые выданы до становления и до момента начала деятельности учреждения юстиции, которые осуществляют регистрацию прав на недвижимое имущество и сделок с ним, считаются юридически действительными. Помимо этого, необходимо знать, что становление системы названных учреждений юстиции завершилось к 1 января 2000 г.

В случаях рассмотрения такого специфического права, как право пожизненного наследуемого владения земельным участком, необходимо заметить, что с момента введения в действие Земельного Кодекса РФ (30 октября 2001 г.), земельные участки на праве пожизненного наследуемого владения больше не предоставляются (ст. 21 ЗК РФ). Кроме этого, люди, которые имели на таком праве земельные участки, могут получить их в свою собственность один раз бесплатно. По сути, можно сказать, что государство шаг за шагом последовательно ликвидирует право пожизненного наследуемого владения земельными участками.

Те граждане, которые уже имеют земельные участки на таком праве, могут эту землю только передать по наследству (распорядиться могут только так). Основанием для государственной регистрации передачи права пожизненного наследуемого владения земельным участком по наследству является свидетельство о праве на наследство.

Ссылаясь на ГК РФ можно указать, что получение земельного участка в порядке наследования не нуждается в каком-то специальном разрешении. Это добавление, в свою очередь, не имеет правового содержания. Если говорить конкретно то это даже учет общественно-политической обстановки в России в момент подготовки и дальнейшего принятия третей части ГК РФ (споры о возможности совершения сделок с земельными участками, дискуссии о частной собственности на землю, дебаты о возможности приобретать земельные участки иностранными гражданами и т.п.).

Земельные доли (доли в праве общей собственности на земельный участок) также могут передаваться по наследству. Это наследование происходит также как и наследование земельных участков.

Из общих правил наследования земельных участков можно исключить те случаи, когда эти участки принадлежат членам фермерских хозяйств. Участок крестьянского (фермерского) хозяйства должно оставаться в коллективной (совместной) собственности других членов этого хозяйства. Но при этом, если наследник фермерского хозяйства сам не состоит в нем, то он может получить компенсацию, которая соизмерима доле наследуемого имущества, которое находится в фермерском хозяйстве. Если нет определенного соглашения у членов хозяйства и наследником о долях этого имущества, то эта доля является равной доле остальных членов хозяйства. В таких случаях, когда наследник решает вступить в члены такого хозяйства, компенсация ему не присуждается, в соответствии с п. 2 ст. 1179 ГК РФ.

Когда крестьянское (фермерское) хозяйство прекращает свою деятельность (п.1 ст.258 ГК РФ) вследствие смерти ее члена (например, если он был единственным членом данного хозяйства, также если наследники не желают вести это хозяйство в будущем), то имущество хозяйства должно быть поделено между наследниками (п.9 ст. 1179 ГК РФ).

Специфика такого раздела наследуемого земельного участка указана в ст. 1182 ГК РФ. Основываясь на данную статью, раздел земельного участка, который отходит наследникам на праве общей собственности, должен производиться учитывая минимальный размер земельного участка, который был установлен для участков 
соответствующего целевого назначения. Этот минимальный размер отображен в актах земельного законодательства (и регионального, и федерального), которые посвящены землям различного назначения.

Если такой раздел земельного участка не является возможным (с учетом минимального размера), то данный участок отходит тому наследнику, у которого есть преимущественное право получение в счет своей наследственной доли этого земельного участка. Иные наследники получают компенсацию (денежную или иную).

Преимущественное право на получение в счет своей наследственной доли земельного участка имеют только члены крестьянского (фермерского) хозяйства перед наследниками, не являющимися таковыми.

Ссылаясь на ч. 2 п. 2 ст. 1182 ГК РФ, можно сказать, что в случаях, если у наследников нет преимущественного права на получение земельного участка или они ими не воспользовались, то владение, пользование и распоряжение землей наследниками должно быть на условиях общей долевой собственности.

Если земли сельскохозяйственного назначения являются одной из составляющих выморочного имущества, то они отходят в фонд перераспределения земель. Данный фонд был сформирован в целях перераспределения земель для сельскохозяйственного производителя, реализации и расширения подсобных хозяйств, крестьянских (фермерских) хозяйств, ведения садоводства, огородничества, животноводства, выпаса скота (статья 80 ЗК РФ). Исключительно федеральные законы и иные нормативно-правовые акты Российской Федерации имеют право предоставлять земельные участки из фонда перераспределения земель сельскохозяйственного назначения.

Таким образом, проанализировав законодательство Российской Федерации можно сказать, что система наследования земельных участков должна опираться на конструкцию земли, как главной вещи, поскольку еще исходя из основ римского права, земля считалась главной вещью, а сооружения на ней - принадлежностью, что нашло отражение и в современном праве. Кроме того, обоснована необходимость наделения наследника земельного участка преимущественным правом на получение в счет наследственной доли здания (сооружения), находящегося на данном земельном участке и принадлежавшего наследодателю на праве собственности, в ситуациях, когда завещанием не определены конкретные наследники здания (сооружения) и земельного участка. Представляется, что наличие указанного преимущественного права соответствует реализации принципа единой судьбы права собственности на земельный участок и объекты недвижимости.

$$
* * *
$$

1. Конституция Российской Федерации. Принята всенародным голосованием 12.12.1993 (с учетом поправок, внесенных Законами РФ о поправках к Конституции РФ от 30.12.2008 № 6-ФКЗ, от 30.12.2008 № 7-ФКЗ, от 05.02.2014 № 2-ФКЗ) // Собрание законодательства РФ. 2014. № 9, ст. 851.

2. Гражданский кодекс Российской Федерации от 30 ноября 1994 года № 51-Ф3. Часть третья // Собрание законодательства РФ. 1994. № 32, ст. 3301.

3. Земельный кодекс Российской Федерации от 25.10.2001 № 136-Ф3 // Российская газета. 2001. 30 октября.

4. Федеральный закон от 21 июля 1997 года № 122-Ф3 «О государственной регистрации прав на недвижимое имущество и сделок с ним» // Собрание законодательства РФ. 1997. № 30, ст. 3594.

5. Жмурко С.Е. Садовые, огородные и дачные земельные участки: особенности владения, пользования и распоряжения. Выпуск 16. 2-е издание, переработанное и дополненное. М.: ЗАО «Библиотечка РГ», 2016. $144 \mathrm{c}$.

6. Оганисян И.А. Наследование земельных участков и актуальные проблемы // НаукаПарк. № 6 (26). 2014. - C. 24-27.

7. Тужилова-Орданская Е.М. Проблемы защиты прав на недвижимость в гражданском праве России: Монография. - М.: ООО «Издательский дом «Буквовед». 2007. 448 с. 